\title{
DRESS Syndrome Without Eosinophilia Induced by Carbamazepine: a Case Report
}

\author{
Slobodan M. Janković1,2, Biljana D. Popovska-Jovičicín,, \\ Radiša T. Pavlovićs, Radica S. Živković-Zarić ${ }^{1}$
}

\author{
${ }^{1}$ Department of Pharmacology and toxicology, Faculty of Medical Sciences, University of Kra- \\ gujevac, Kragujevac, Serbia \\ ${ }^{2}$ Department of Clinical Pharmacology, Clinical Center Kragujevac, Kragujevac, Serbia \\ ${ }^{3}$ Department of Infectious diseases, Faculty of Medical Sciences, University of Kragujevac, \\ Kragujevac, Serbia \\ ${ }^{4}$ Clinic for Infectious diseases, Clinical Center Kragujevac, Kragujevac, Serbia \\ ${ }^{5}$ Department for Clinical Pharmacy, Faculty of Medical Sciences, University of Kragujevac, \\ Kragujevac, Serbia
}

\section{SUMMARY}

Introduction: Drug rash with eosinophilia and systemic symptoms (DRESS syndrome) is a rare, severe, systemic, drug-induced hypersensitivity syndrome, the most frequently associated with anticonvulsants.

Case Report: A 35-years-old woman with a history of depression and hypothyroidism developed fever $39.5^{\circ} \mathrm{C}$, enlarged, painful neck and axillary lymph nodes, slight facial edema around the mouth, confluent maculopapular rash, and laboratory signs of hepatocellular injury, leukocytosis and lymphopenia, but with normal eosinophil count. The syndrome was evident two weeks after starting carbamazepine, and gradually decreased after withdrawal of this drug and introduction of corticosteroid therapy.

Conclusion: If a patient is taking carbamazepine and develops skin rash as well as fever and swollen lymph nodes, the physician should always check for internal organ damage and possible DRESS syndrome.

Keywords: DRESS syndrome, Carbamazepine, Eosinophilia

\section{INTRODUCTION}

Drug rash with eosinophilia and systemic symptoms (DRESS syndrome) is a rare, severe, systemic drug reaction which is a kind of drug-induced hypersensitivity syndrome, probably a type IV allergy [1]. It occurs with an approximate frequency of $0.1-0.01 \%$ and has a high mortality rate (about $10 \%)$. It was first described in the 1930s in association with phenytoin and, for many years was considered a unique adverse effect of that drug [2]. The drugs most often associated with DRESS syndrome include so-called aromatic anticonvulsants, with carbamazepine almost a quarter of reported cases been connected with carbam- 
Table 1. Laboratory findings during hospitalization

\begin{tabular}{|c|c|c|c|c|c|c|}
\hline & $\begin{array}{c}23.12 .2019 . \\
\text { day } 1\end{array}$ & $\begin{array}{c}30.12 .2019 \\
\text { day } 8\end{array}$ & $\begin{array}{c}31.12 .2019 . \\
\text { day } 9\end{array}$ & $\begin{array}{c}2.1 .2020 . \\
\text { day } 11\end{array}$ & $\begin{array}{c}6.1 .2020 . \\
\text { day } 15\end{array}$ & $\begin{array}{c}9.1 .2020 . \\
\text { day } 18\end{array}$ \\
\hline WBC $\left(10^{9} / \mathrm{l}\right)$ & 2.83 & 5.66 & 6.76 & 11.9 & 16.35 & 8.84 \\
\hline $\begin{array}{l}\text { Neutrophils } \\
\left(10^{9} / \mathrm{l}\right) /(\%)\end{array}$ & $1.48 / 52.13$ & $4.44 / 78,38$ & $5.0 / 73.93$ & $4.9 / 41.2$ & $4.4 / 27.14$ & $3.51 / 39.73$ \\
\hline $\begin{array}{c}\text { Lymphocytes } \\
\left(10^{9} / \mathrm{l}\right) /(\%)\end{array}$ & $1.09 / 38.42$ & $0.65 / 11.48$ & $0.59 / 8.71$ & $5.5 / 46.5$ & $10.17 / 62.22$ & $4.0 / 45.22$ \\
\hline $\begin{array}{l}\text { Monocytes } \\
\left(10^{9} / \mathrm{l}\right) /(\%)\end{array}$ & $0.22 / 7.71$ & $0.49 / 8.63$ & $1.01 / 14.9$ & $0.9 / 7.1$ & $1.56 / 9.54$ & $1.3 / 14.67$ \\
\hline $\begin{array}{l}\text { Eosinophils } \\
\left(10^{9} / \mathrm{l}\right) /(\%)\end{array}$ & $0.03 / 0.96$ & $0.08 / 1.47$ & $0.14 / 2.14$ & $0.4 / 3$ & $0.06 / 3.35$ & $0.0 / 0.03$ \\
\hline $\begin{array}{l}\text { Basophils } \\
\left(10^{9} / \mathrm{l}\right) /(\%)\end{array}$ & $0.02 / 0.78$ & $0.0 / 0.04$ & $0.02 / 0.32$ & $0.3 / 2.2$ & $0.12 / 0.75$ & $0.03 / 0.35$ \\
\hline AST (IU/l) & 179 & 509 & & 115 & 92 & 30 \\
\hline ALT (IU/L) & 345 & 634 & & 266 & 312 & 133 \\
\hline LDH (IU/l) & 645 & 1510 & & 1071 & 750 & 551 \\
\hline GGT (IU/L) & & 608 & & 859 & 924 & 580 \\
\hline $\operatorname{ALP}(I U / l)$ & & 265 & & 433 & 575 & 316 \\
\hline
\end{tabular}

azepine [3]. Also, according to the literature, allopurinol, minocycline, lamotrigine, as well as abacavir could induce DRESS syndrome [1].

Typical signs of DRESS syndrome include eosinophilia, rash, fever, atypical lymphocytes in peripheral blood, lymphadenopathy, and inflammation of one or more internal organs (liver is the most often involved). However, although being a key element of the title of the syndrome, eosinophilia is not always present, and in almost a third of the cases the count of eosinophils will be within normal limits, while lymphocyte count may be disturbed [1]. In such cases, with normal eosinophil counts, clinicians may find it difficult to make a diagnosis of the DRESS syndrome. However, considering the entire clinical picture and knowing which drug groups have the highest risk of DRESS should direct a clinician's mind towards this rare, but potentially very harmful drug reaction.

We here report an atypical case of DRESS syndrome without eosinophilia, probably induced by carbamazepine and successfully treated by discontinuation of this drug and administration of steroids systemically. We obtained informed patient consent to publish this case report.

\section{CASE REPORT}

A 35-years-old woman with a history of depression and hypothyroidism was admitted to the Clinic for Infectious diseases (Clinical Center, Kragujevac, Serbia) for having fever $39.5^{\circ} \mathrm{C}$, enlarged, painful neck and axillary lymph nodes, slight facial edema around the mouth and confluent maculopapular rash covering whole body except head, but including palms and soles. Blood count showed lymphopenia, and blood biochemistry revealed elevated aminotransferases (AST more than three fold above the upper normal level, and AST more than five fold above the upper normal level) and lactate dehydrogenase (more than two times above the upper normal level). Three weeks before the admission the patient was prescribed carbamazepine (200 mg b.i.d., not taking into account its high potential to induce metabolism of other drugs), olanzapine (10 mg once daily), venlafaxine (75 mg once daily) and clonazepam (2 mg once daily). For many years' patient has been taking levothyroxine (100 mcg once daily) and occasionally zolpidem (10 mg once daily). One week before the admission, the patient developed fever and was treated out of the hospital with penicillin and gentamicin, since her family physician could not explain origin of the fever, and was afraid of possible bacterial infection. However, since her condition worsened, she was hospitalized and carbamazepine, olanzapine and antibiotics were discontinued.

The patient continued to be febrile, depressed, adynamic and dehydrated. Treatment of depression was continued with venla- 


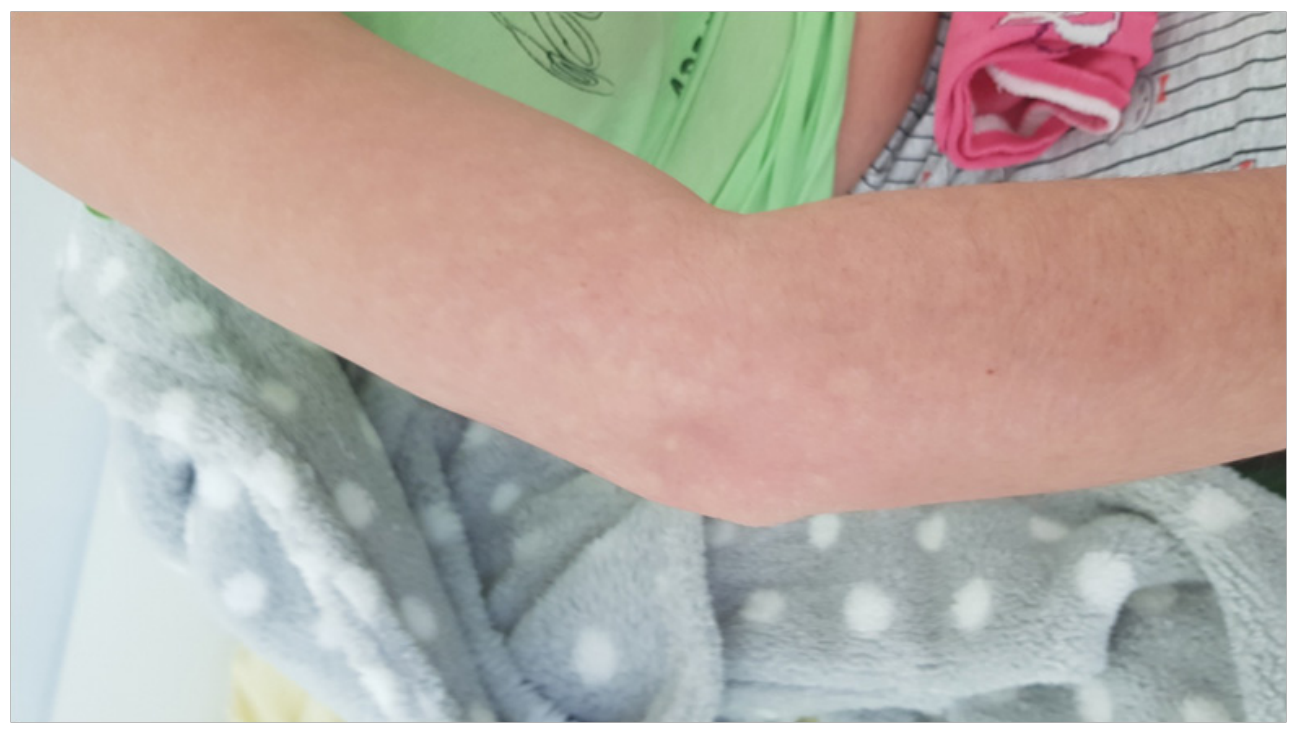

faxine, clonazepam and occasional zolpidem, also oral prednisone $60 \mathrm{mg}$ daily was given for 4 days, and then gradually tapered off. After 7 days of hospitalization the patient's condition was significantly improved: skin rash disappeared from the trunk, and was visible only on distal parts of both upper and lower extremities, including palms and soles (Figures 1-2). On both sides of the neck, the enlarged lymph nodes shrank, and the patient became afebrile. Liver enzymes continued to be elevated, but from the 10th day of hospitalization their levels gradually dropped (Table 1 ).

During the first 7 days of hospitalization, the patient was sent to abdominal ultrasonography, which showed somewhat enlarged liver (135mm to $140 \mathrm{mmin}$ diameter), with normal echo-texture. Whole body computerized tomography (CT) scan demonstrat- ed bilaterally enlarged lymph axillary nodes up to $20 \mathrm{~mm}$, solitary mediastinal and retroperitoneal lymph nodes up to $7 \mathrm{~mm}$ and enlarged liver up to $185 \mathrm{~mm}$ (the longest diameter) with normal parenchyma. Chest radiography was normal. Serological assays for hepatitis B and $C$ virus, HIV, EBV and CMV were negative. No tests have been performed to prove HHV6 reaction. Levels of IgG, IgM, AMA, ANA, ANCA antibodies were normal with slightly decreased IgA. Blood cultures were also negative. Eighteen days after admission, her clinical status and laboratory findings improved (Table 1) and she was discharged continuing her therapy with venlafaxine and clonazepam, while $10 \mathrm{mg}$ of prednisone was administered daily for further 5 days, then reduced to $5 \mathrm{mg}$ daily for further week, and after that stopped. The patient felt completely well, and none of

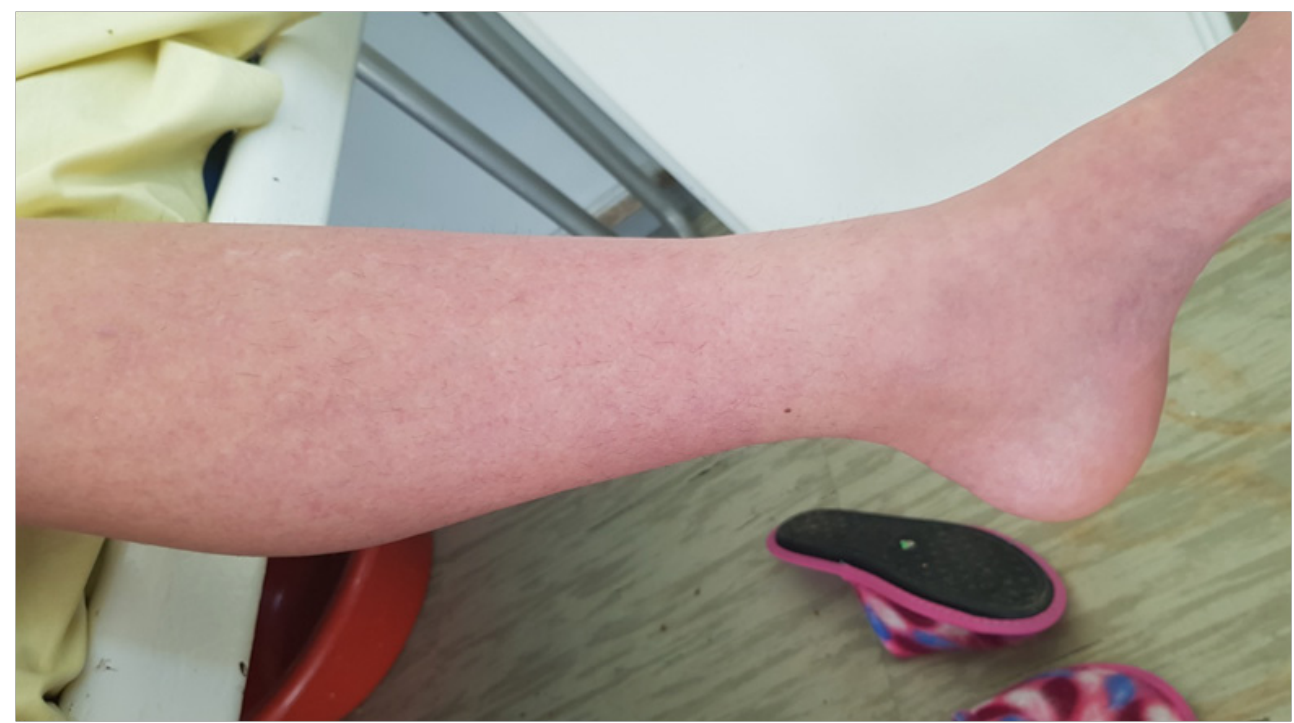

Figure 2. Skin rash on lower extremities in the resolution phase 
Table 2. Laboratory findings during hospitalization

\begin{tabular}{|c|c|c|c|c|c|}
\hline & $\begin{array}{c}\text { Please answer the following questionnaire and give the } \\
\text { pertinent score }\end{array}$ & Yes & No & Do Not Know & Score \\
\hline 1 & Are there previous conclusive reports on this reaction? & 1 & 0 & 0 & \\
\hline 2 & $\begin{array}{l}\text { Did the adverse event occur after the suspected drug was } \\
\text { administered? }\end{array}$ & 2 & -1 & 0 & 2 \\
\hline 3 & $\begin{array}{l}\text { Did the adverse reaction improve when the drug was } \\
\text { discontinued or a specific antagonist was administered? }\end{array}$ & 1 & 0 & 0 & 1 \\
\hline 4 & $\begin{array}{l}\text { Did the adverse reaction reappear when the drug was } \\
\text { readministered? }\end{array}$ & 2 & -1 & 0 & \\
\hline 5 & $\begin{array}{l}\text { Are there alternative causes (other than the drug) that } \\
\text { could have on their own caused the reaction? }\end{array}$ & -1 & 2 & 0 & 2 \\
\hline 6 & Did the reaction reappear when a placebo was given? & -1 & 1 & 0 & \\
\hline 7 & $\begin{array}{l}\text { Was the drug detected in the blood (or other fluids) in } \\
\text { concentrations known to be toxic? }\end{array}$ & 1 & 0 & 0 & \\
\hline 8 & $\begin{array}{l}\text { Was the reaction more severe when the dose was in- } \\
\text { creased or less severe when the dose was decreased? }\end{array}$ & 1 & 0 & 0 & \\
\hline 9 & $\begin{array}{l}\text { Did the patient have a similar reaction to the same or } \\
\text { similardrugs in any previous exposure? }\end{array}$ & 1 & 0 & 0 & \\
\hline 10 & $\begin{array}{l}\text { Was the adverse event confirmed by any objective evi- } \\
\text { dence? }\end{array}$ & 1 & 0 & 0 & \\
\hline \multicolumn{2}{|r|}{ Total } & & & & 5 \\
\hline
\end{tabular}

the described signs and symptoms recurred at the check-up visit one month after discharge from the hospital.

\section{DISCUSSION}

According to the European Registry of Severe Cutaneous Adverse Reactions (RegiSCAR) scoring system [4], our patient experienced probable (score 4) DRESS syndrome, and causal relation with carbamazepine as assessed by Naranjo adverse effects causality assessment scale [5] was also rated as probable (Naranjo score 5) (Table 2). Lack of eosinophilia was major confounder when differential diagnosis was considered with our patient, since according to literature reviews it is present in $66-95 \%$ of patients [6]. However, heterogeneous manifestations of the DRESS syndrome are rather a rule than exception [7], and eosinophilia is not universally observed in all cases. Besides, our patient had a few findings that could be considered as „pearls” for making diagnosis of DRESS syndrome: measles-like rash, facial edema and liver damage as the most frequent internal organ involvement with this syndrome [7]. According to the literature these symptoms could be caused also by other diseases such as viral hepatitis, connective tissue diseases, idiopathic hypereosinophilia [1].

Among the psychotropic drugs carbamazepine was causally linked to DRESS syndrome the most frequently in the past: recent systematic review of published case reports and other types of observational studies involving patients with DRESS syndrome found that carbamazepine, lamotrigine, phenytoin, valproate, and phenobarbital were the most implicated drugs [8]. Carbamazepine, lamotrigine, phenytoin and phenobarbital share a commonality in their molecular structure that could be important for pathophysiological mechanism of the events underlying the DRESS syndrome - aromaticity [9]. Why aromatic antiepileptic drugs are more prone to cause DRESS syndrome is not known but one of the published case series showed that patients who experienced DRESS syndrome after taking one of the aromatic antiepileptic drugs tolerated non-aromatic anticonvulsants well later on [10]. It is typical for carbamazepine that there is latent period of 2-4 weeks after starting treatment until the DRESS syndrome appears [1]; the same was observed in our patient, with the onset of the first symptoms two weeks following administration of carbamazepine. Although exact pathophysiology of carbamazepine-induced DRESS syndrome is unknown, majority of preclinical and clinical studies agree that it is immunological in nature, and accompanied with highly increased specific and non-specific activity of T lymphocytes [11].

Our patient had hepatocellular lesion 
of the liver, since the $\mathrm{R}$ ratio (the ratio of the ALT to the ALP relative to their respective upper limits of normal) was 5.9 [12]. Carbamazepine may increase serum levels of gamma glutamyl transferase and alkaline phosphatase to a certain extent without damage of liver cells, but elevation of aminotransferases more than 5 times their upper normal limits is always associated with cell damage. Cessation of carbamazepine therapy in our patient was followed by gradual normalization of serum levels of liver enzymes, taking more than two weeks for the values to drop within normal range.

Starting therapy with full dose of carbamazepine is recognized risk factor for DRESS syndrome, since gradual introduction of the drug with small initial doses can prevent immunological reactions through some kind of desensitization [11]. The initial dose in our patient was $400 \mathrm{mg}$ daily, and this kind of dosage regimen could have been contributing factor that resulted in the DRESS syndrome. It was recently found that DRESS syndrome is more frequent in persons with HLA- $A^{\star} 31: 01$ alleles (odds ratio may be as high as 32) [13], but this kind of genetic testing was not available in the hospital where our patient was treated, precluding determination of her HLA status.

Condition of our patient gradually improved with prednisone therapy; however, true therapeutic effectiveness of steroids in DRESS syndrome was not established, because there are many cases of patients who recovered completely without any therapy apart from withdrawal of the drug [14]. Corticosteroid therapy is probably more important for severe forms of DRESS syndrome, where other immunosuppressant's sometimes have to be used, like cyclosporine, which showed good efficacy [14]. Our patient experienced mild DRESS syndrome, therefore resolution of signs and symptoms could not be ascribed to prednisone without reserve. High-dose intravenous immunoglobulin therapy has been established by various experts in USA as the first line treatment of DRESS syndrome and Toxic epidermal necrolysis based on findings that intravenous immunoglobulins can reduce Fas-FasL interaction $[15,16]$.

\section{CONCLUSION}

In conclusion, when skin reactions are observed in patients who take carbamazepine, a physician should always search for involvement of internal organs, especially if patient is febrile and has enlarged lymph nodes. Lack of eosinophilia in blood count should not be used as an argument to reject diagnosis of the DRESS syndrome in the first place, because there is high variability of clinical manifestations, and diagnostic decisions should be based on complete clinical and laboratory status of the patient.

\section{CONFLICT OF INTEREST}

All authors declare no conflict of interest.

\section{REFERENCES}

1. Cacoub P, Musette P, Descamps V, Meyer O, Speirs C, Finzi L, Roujea JC . The DRESS syndrome: a literature review. Am J Med. 2011;124(7):588-97. DOI: 10.1016/j.amjmed.2011.01.017 .PMID: 21592453.

2. Cardones AR. Drug reaction with eosinophilia and systemic symptoms (DRESS) syndrome. Clin Dermatol. $2020 ; 38(6)$ :702-711. doi: 10.1016/j.clindermatol.2020.06.008. PMID: 33341203.

3. Shiohara T, Mizukawa Y. Drug-induced hypersensitivity syndrome (DiHS)/drug reaction with eosinophilia and systemic symptoms (DRESS): An update in 2019. Allergol Int. 2019;68(3):301-308. DOI: 10.1016/j.alit.2019.03.006. PMID: 31000444.

4. Kardaun SH, Sekula P, Valeyrie-Allanore L, Liss $Y$, Chu CY, Creamer D, Sidoroff A, LNaldi L, Mockenhaupt $M$, Roujeau JC, RegiSCAR study group . Drug reaction with eosinophilia and systemic symptoms (DRESS): an original multisystem adverse drug reaction. Results from the prospective RegiSCAR study. Br J Dermatol. 2013;169(5):1071-80. DOI: 10.1111/ bjd.12501. PMID: 23855313.

5. Naranjo CA, Busto U, Sellers EM, Sandor P, Ruiz I, Roberts EA, Janecek E, Domecq C, Greenblatt DJ. A method for estimating the probability of adverse drug reactions. Clin PharmacolTher. 1981;30(2):239-45. DOI: 10.1038/clpt.1981.154. PMID: 7249508.

6. Cho Y-T, Yang C-W, Chu C-Y. Drug Reaction with Eosinophilia and Systemic Symptoms (DRESS): An Interplay among Drugs, Viruses, and Immune System. Int J Mol Sci. 2017;18(6). DOI: 10.3390/ ijms18061243. PMID: 28598363

7. Isaacs M, Cardones AR, Rahnama-Moghadam S. DRESS syndrome: clinical myths and pearls. Cutis. 2018;102(5):322-6. PMID: 30566546

8. Bommersbach TJ, Lapid MI, Leung JG, Cunningham JL, Rummans TA, Kung S. Management of Psychotropic Drug-Induced DRESS Syndrome: A Systematic Review. Mayo Clin Proc. 2016;91(6):787801. DOI: $10.1016 /$ j.mayocp. 2016.03.006. PMID: 27126302 
9. Lee JE, Min KR, Kim SH, Kim AH, Kim ST. Analysis of Adverse Drug Reactions with Carbamazepine and Oxcarbazepine at a Tertiary Care Hospital. Yonsei Med J. 2020;61(10):875-879. doi: 10.3349/ ymj.2020.61.10.875. PMID: 32975062.

10. Godhwani N, Bahna SL. Antiepilepsy drugs and the immune system. Ann Allergy Asthma Immunol. 2016;117(6):634-40. DOI: 10.1016/j. anai.2016.09.443. PMID: 27979020

11. Kim HK, Kim DY, Bae EK, Kim DW. Adverse Skin Reactions with Antiepileptic Drugs Using Korea Adverse Event Reporting System Database, 2008-2017. J Korean Med Sci. 2020;35(4):e17. DOI: 10.3346/ jkms.2020.35.e17. PMID: 31997613.

12. Andrade RJ, Chalasani N, Björnsson ES, Suzuki A, Kullak-Ublick GA, Watkins PB, Devarbhavi H, Merz M, Lucena MI, Kaplowitz N, Aithal GP. Drug-induced liver injury. Nat Rev Dis Primers. 2019 ;5(1):58. DOI: 10.1038/s41572-019-0105-0. PMID: 31439850.

13. Ksouda K, Affes $\mathrm{H}$, Mahfoudh N, Chtourou L, Kammoun A, Charfi A. HLA-A*31:01 and carbamazepine-induced DRESS syndrom in a sample of North African population. Seizure. 2017;53:42-6. DOI: 10.1016/j.seizure.2017.10.018. PMID: 26696029

14. Nguyen E, Yanes D, Imadojemu S, Kroshinsky D. Evaluation of Cyclosporine for the Treatment of DRESS Syndrome. JAMA Dermatol. 2020;156(6):704706. DOI 10.1001/jamadermatol.2020.0048. PMID: 32159726

15. Kandolf-Sekulovic L. An update on diagnosis and treatment of toxic epidermal necrolysis. Serbian J Dermatology Venereol. 2011; 3(2):53-64. DOI: 10.2478/v10249-011-0037-5.

16. Santhamoorthy P, Alexander JK, Alshubaili A. Intravenous immunoglobulin in the treatment of drug rash eosinophilia and systemic symptoms caused by phenytoin. Ann Indian Acad Neurol. 2012; 15(4):320-322. DOI: 10.4103/0972-2327.104348. PMID: 23349605. 


\section{DRESS sindrom bez eozinofilije uzrokovan karbamazepinom: prikaz slučaja}

Slobodan M. Janković1,2, Biljana D. Popovska-Jovičićs, ${ }^{3,4}$ Radiša T. Pavlovićs, Radica S. Živković-Zarić ${ }^{1}$

\footnotetext{
${ }^{1}$ Katedra za Farmakologiju i toksikologiju, Fakultet Medicinskih Nauka, Univerziteta u Kragujevcu, Kragujevac, Srbija

${ }^{2}$ Služba za Kliničku farmakologiju, Klinički Centar Kragujevac, Kragujevac, Srbija

${ }^{3}$ Katedra za Infektivne bolesti, Fakultet Medicinskih Nauka, Univerziteta u Kragujevcu, Kragujevac, Srbija

${ }^{4}$ Klinika za Infektivne Bolesti, Klinički Centar Kragujevac, Kragujevac, Srbija

${ }^{5}$ Katedra za Kliničku farmaciju, Fakultet Medicinskih Nauka, Univerziteta u Kragujevcu, Kragujevac, Srbija
}

\section{KRATAK SADRŽAJ}

Uvod: Ospa praćena eozinofilijom i sistemskim simptomima (DRESS sindrom) je teško, retko, sistemsko stanje preosetljivosti na neki lek, koje najčešće izazivaju antikonvulzivi.

Prikaz slučaja: Žena stara 35 godina koja se lečila od depresije i hipotireoidizma je dobila temperaturu $39.5^{\circ} \mathrm{C}$, uvećane limfne žlezde na vratu i u pazušnoj jami, otok oko usana i ospu po koži. Laboratorijski parametri su pokazali oštecenje jetre, leukocitozu i limfopeniju, dok je broj eozinofila bio normalan. Sindrom se pojavio dve nedelje posle uvodjenja karbamazepina, a povukao se posle obustave terapije $i$ uvodjenja kortikosteroida.

Zaključak: Ukoliko pacijent uzima karbamazepin, a pojavi se ospa na kozi kao i povisena temperatura i uvecane limfne zlezde, lekar treba da proveri da li postoji ostecenje unutrasnjih organa i moguci DRESS sindrom.

Ključne reči: DRESS sindrom, karbamazepin, eozinofilija 